\title{
Toxicological Effects of Para-Phenylenediamine on kidneys of Female Albino Rats
}

\author{
Omima R. Mohamed ${ }^{b}$, Nermeen A. M. Hassan ${ }^{a}$, \\ Eslam S. Metwallya ${ }^{a}$ and Asmaa Y.A. Hussein ${ }^{a}$ \\ Forensic medicine and Clinical Toxicology Department, Faculty of Medicine, \\ Benha University, Egypt

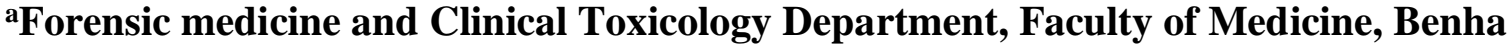 \\ University, Egypt \\ ${ }^{\text {b} A s s i s t a n t ~ l e c t u r e r ~ o f ~ F o r e n s i c ~ m e d i c i n e ~ a n d ~ C l i n i c a l ~ T o x i c o l o g y ~ D e p a r t m e n t, ~ F a c u l t y ~ o f ~}$ \\ Medicine, Benha University, Egypt
}

*Corresponding Author: Omima R. Mohamed. Email: omimarefaat1331@gmail.com

\begin{abstract}
Background: Para-phenylenediamine (PPD) is a chemical substance used mainly in synthesis of printing ink, photographic solutions, photocopying, temporary tattoo and dark colored cosmetics. Continuous exposure to Para-phenylenediamine has side effect on both kidney structure and function in female albino rats. Aim of work: This study aimed to evaluate the toxicological effects of paraphenylenediamine on the kidneys of female albino rats. Methods: The total experimental period was 60 days, 72 female adult albino rats were used as follows: negative control; positive control (distilled water on the shaved skin, $\mathrm{H}_{2} \mathrm{O}_{2} 6 \%$ on the shaved skin, distilled water on the hairy skin and $\mathrm{H}_{2} \mathrm{O}_{2} 6 \%$ on the hairy skin); test group I: PPD solution in distilled water $(10 \mathrm{mg} / \mathrm{kg} /$ day $)$ on shaved skin \& on hairy skin; test group II: PPD dissolved in $\mathrm{H}_{2} \mathrm{O}_{2} 6 \%(10 \mathrm{mg} / \mathrm{kg} /$ day $)$ on shaved skin\& on hairy skin. The level of serum creatinine and blood urea was measured and the renal tissues were examined by light and transmission electron microscope. As PPD generate reactive oxygen species (ROS), which is highly nephrotoxic.
\end{abstract}

Key words: PPD, $\mathrm{H}_{2} \mathrm{O}_{2}$, oxidative stress, kidney.

\section{INTRODUCTION}

Para-phenylenediamine (PPD) is a toxic and dangerous material which is commonly present in each home in the developing countries. Unfortunately, both women's and men are exposed to PPD during hair dyeing as hair dyes containing PPD are much cheaper than other hair dyes present in the markets (Hassan et al., 2017).

The art of hair dyeing was used as early as 5000 years before Christian age among the Egyptians. The hair dying was used in Egyptian times when mummies were dyed with henna (Malik et al., 2016).

Recently PDD has been mixed with henna to give black color instead of the orange color given by natural henna. Also, PPD added to the natural henna to fasten the tattooing process, while natural henna staining takes up to 4 hours, addition of PPD can reduce this time to an hour or two. Thus, a new pattern of exposure to PPD has been recognized through the henna art which increases the developing adverse health effects of PPD (Al Saif, 2016).

The most dangerous toxic effects of hair dye occur through skin absorption, ingestion, and inhalation. It can lead to damage of internal body organs and death depending on both the dose and concentration of PPD (Abass et al., 2017).

There are many mechanisms of renal injury due to hair dye poisoning. The direct toxic effect of PPD on kidney due to its aromatic structure, which increases reabsorption and concentration of PPD in renal tubules and can lead to acute renal failure. It can cause rhabdomyolysis through deposition of 
myoglobin casts in the renal tubules PPD causes hemolysis resulting in hemoglobinuria which lead to acute tubular necrosis and acute renal failure. Furthermore, the hypovolemia can complicate renal failure (Elkhomainy, 2017).

\section{AIM OF THE WORK}

The present study aimed to illustrate the toxicological effects of (PPD) on the kidney in female albino rats.

\section{MATERIALS AND METHODS \\ Animals}

The present work was carried out on seventy-two female albino rats weighting 200 $( \pm 10) \mathrm{g}$.

As PPD used mainly by human females in hair dying. All rats were allowed for one week of adaptation (taking food \& water without any medications) in Faculty of Veterinary Medicine, Banha University, Moshtohor. This research was accepted by the Ethical Committee, Banha Faculty of Medicine.

\section{Chemicals}

Para-phenylenediamine (PPD) was brought from "Sigma Company"; (USA) in a form of white powder of purity $\pm 98 \%, \mathrm{H}_{2} \mathrm{O}_{2} 6 \%$ was brought from "Sigma Company"; (USA) and Distilled water was purchased from Misr Chemical Industries Co, Cairo, Egypt.

\section{Animals grouping}

At the beginning of the study, rats were randomly distributed to four groups:

\section{Group I (negative control group):}

8 rats were left without intervention to measure the basic parameters, free access to food and distilled water was allowed.

\section{Group II (positive control group):}

32 rats were equally distributed to four subgroups (8 rats in each sub group) as follow:

- Control group IIa: 8 rats were treated by dermal application of $4 \mathrm{ml}$ of distilled water/day, on the shaved part of skin.

- Control group IIb: 8 rats were treated with 2 $\mathrm{ml}$ of $\mathrm{H}_{2} \mathrm{O}_{2} 6 \%$ /day, by dermal application on the shaved part of skin.
- Control group IIc: 8 rats were treated by dermal application of $4 \mathrm{ml}$ of distilled water on the hairy skin/day.

- Control group IId: 8 rats were treated by dermal application of $2 \mathrm{ml}$ of $\mathrm{H}_{2} \mathrm{O}_{2} 6 \%$ on the hairy skin /day.

Test Group I: 16 rats were treated with $(10 \mathrm{mg} / \mathrm{kg}$ PPD dissolved in distilled water). This group was equally divided into two subgroups (8 rats in each sub group) as follows:

- Test Group Ia: 8 rats were treated with PPD solution in distilled water $(10 \mathrm{mg} / \mathrm{kg}$ body weight/day), by dermal application on shaved skin (ElHelaly and Shaker, 2014 and AlSeigini et al., 2014).

- Test Group Ib:8 rats were treated with PPD solution in distilled water

(10 mg/ kg body weight/day), by dermal application on hairy skin.

Test Group II: 16 rats were treated with (10mg/kg PPD dissolved in $\mathrm{H}_{2} \mathrm{O}_{2} 6 \%$ ). This group was equally divided into two subgroups (8 rats in each sub group) as follows:

- Test Group IIa: 8 rats were treated with PPD solution dissolved $\mathrm{inH}_{2} \mathrm{O}_{2} 6 \%(10 \mathrm{mg} / \mathrm{kg} /$ day), by dermal application on shaved skin (Zanoni et al., 2015 and Lee and Lee, 2006).

- Test Group IIb: 8 rats were treated with PPD solution dissolved in $\mathrm{H}_{2} \mathrm{O}_{2} 6 \%(10 \mathrm{mg} / \mathrm{kg} /$ day), by dermal application on hairy skin.

\section{Rout of vehicle applications:}

In all test groups (PPD) either dissolved in distilled water or in $\mathrm{H} 2 \mathrm{O} 2$ were applied on skin area about $4 \mathrm{~cm}^{2}$ diameter (around $10 \%$ of the body surface area) at the inter scapular region of rat. The test solution was applied with a syringe and then spread with a spatula over the skin, left for 30 min per day and then washed with tap water (Gouma et al., 2011).

After passage of the experiment period (2 months), all survived animals were sacrificed under ether anesthesia "after 24 hours from the last dose", and encounter laparotomy and thoracotomy; Blood samples from abdominal aorta approximately $10 \mathrm{ml}$ per animal were collected in EDTA tubes protected from light by aluminum foil and processed for genetic study (AlSeiginit et al, 2014)., We obtained plasma immediately after sampling by centrifugation 
(4000 rpm for 10 minutes at $4 \mathrm{C}$ ) and placed it in tubes, which containing a solution of Dascorbic acid, and stored at $20 \mathrm{C}$ for biochemical measurements. Kidneys were exposed, removed and prepared for histopathological examination by light and electron microscope.

\section{Studied parameters:}

\section{A) Biochemical study: Blood samples were taken for estimation of renal function tests (creatinine \& urea).}

B) Histopathological study: Tissue sections of kidney were examined by;

1. Light microscope.

2. Transmission electron microscope (T.E.M).

\section{Statistical Analysis}

Data management and statistical analysis were done using SPSS vs.16. (SpssInc, Chicago, ILL Company).

Categorical data was summarized as numbers and percentages; the significance of difference was tested as follows:

1- Student's $t$-test: Used to compare mean of only two groups of quantitative data.

2- ANOVA test ( $F$ value): Used to compare mean of more than two groups of quantitative data only.

3- Comparison between groups by post hoc test. A $P$ value $<0.05$ was considered statistically significant $(*)$ while $>0.05$ statistically insignificant $\mathrm{P}$ value $<0.01$ was considered highly significant $(* *)$ in all analyses.

\section{A) Biochemical study:}

All control groups presented a non-significant difference $(p>0.05)$ regarding renal functions (blood urea \& serum creatinine level) So, the mean of all control groups was chosen as a representative control group to be compared with the results of the test groups.

The present study presented a highly significant $(p<0.001)$ difference in the blood urea \&serum creatinine levels in both sub test groups Ia \& Ib as compared to controls (Table 9, 10; figure 1, 2) Also, there were highly significant difference between sub test group Ia $\& \mathrm{Ib}$ as regard creatinine level and significant $(p<0.05)$ difference as regard urea level (the sub test group Ia was the most affected) (Table 1, 2).
The results of the present study illustrated a highly significant $(p<0.001)$ difference in blood urea and serum creatinine levels in both sub test groups IIa and IIb as compared to controls. Also, the obtained results revealed no significant $(\mathrm{P}>0.05)$ difference regarding blood urea \&serum creatinine levels in sub test group IIa as compared to sub test group IIb (the sub test group IIb was the least affected) (Table 1, 2).

\section{B) Histopathological results:}

\section{1- Light microscopic examination results:}

Sections examined from the kidneys of all five control groups showed a normal histological structure of kidney. So, image of the negative control group was representative for other control groups (Image 1).

In test groups Ia and Ib, examination of renal sections showed severe destruction in the corpuscles and tubules of the kidney, we detected atrophied corpuscles of the kidney with contracted glomerular tufts and widening of the urinary space, along with degeneration of renal tubular epithelium, luminal dilatation, tubular cast, congestion of blood vessels \& mononuclear cell infiltration as shown in (Image 1).

In test groups IIa and IIb, examination of renal sections showed moderate destructions in the corpuscles and tubules, we detected some atrophic corpuscles with contracted glomerular tufts and widening of the urinary space were detected with degeneration of renal tubular epithelium, luminal dilatation and congestion of blood vessels (Image 1).

\section{2- Electron microscopic examination results:}

Electron microscopic examination of sections from the kidney of all five control groups showed, normal distal and proximal convoluted tubule with normal nucleus \& normal brush border. Images of normal foot processes of podocytes \& normal thickness of basement membrane of the negative control group was representative for other control groups (Image 2, 3, 4).

Test groups Ia and $\mathrm{Ib}$ showed sever destruction in distal convoluted tubules, irregular nuclei with rarefaction due to destructed chromatin, deformation and vacuolations in mitochondria, vacuolations in cytoplasm, destructed and lost brush border, 
infiltrates. Enlargement of podocytes foot processes and thickening of the basement membrane of Bowman's capsule (Image 2, 3, 4).

Test groups IIa and IIb showed moderate destruction of distal convoluted tubules, irregular nuclei and vacuolation in mitochondria \& cytoplasm. Enlargement of foot processes of podocytes, and thickening of basement membrane of Bowman's capsule (Image 2, 3, 4).

Table (1): Comparison between the studied groups according to blood urea level.

\begin{tabular}{|l|c|l|l|l|l|l|l|}
\hline & \multicolumn{6}{|c|}{ Blood urea level. } & \multicolumn{2}{l|}{ Control group } \\
\cline { 2 - 8 } & Mean & \pm SD & Min & Max & $\begin{array}{l}\text { Post } \\
\text { hoc }\end{array}$ & $\begin{array}{l}\text { St t } \\
\text { test }\end{array}$ & P value \\
\hline Control group & 39.03 & 0.46 & 38.6 & 39.8 & & & \\
\hline Test group Ia & 51.38 & 1.51 & 49.00 & 53.00 & $\alpha$ & 22.19 & $<0.001^{* *}$ \\
\hline Test group Ib & 50.25 & 1.49 & 49.00 & 53.00 & $\alpha, \beta$ & 20.39 & $<0.001^{* *}$ \\
\hline Test group IIa & 42.13 & 0.83 & 41.00 & 43.00 & $\alpha, \beta, \gamma$ & 9.21 & $<0.001^{* *}$ \\
\hline Test group IIb & 41.63 & 0.74 & 41.00 & 43.00 & $\alpha, \beta, \gamma$ & 8.41 & $<0.001^{* *}$ \\
\hline ANOVA test & 207.8 & & & & & \\
\hline P value & $<0.001^{* *}$ & & & & & \\
\hline
\end{tabular}

$\alpha$ : sig versus control group $\quad \beta$ : sig versus Gp Ia $\quad \gamma$ : sig versus Gp Ib $\delta$ : sig versus Gp IIa $\quad * *$ : highly significant

Table (2): Comparison between groups according to serum creatinine level.

\begin{tabular}{|c|c|c|c|c|c|c|c|}
\hline & & Ser & n crea & nine le & & Contr & 1 group \\
\hline & Mean & $\pm \mathrm{SD}$ & Min & Max & Post hoc & St t test & $\mathrm{P}$ value \\
\hline Control group & .61 & 0.03 & 0.56 & 0.64 & & & \\
\hline Test group Ia & 2.50 & 0.41 & 2.00 & 3.00 & $\alpha$ & 13.13 & $<0.001 * *$ \\
\hline Test group Ib & 2.06 & 0.12 & 1.90 & 2.20 & $\alpha, \beta$ & 33.67 & $<0.001 * *$ \\
\hline Test group IIa & 1.13 & 0.14 & 0.90 & 1.30 & $\alpha, \beta, \gamma$ & 10.36 & $<0.001 * *$ \\
\hline st group IIb & 1.01 & 0.10 & 0.90 & 1.10 & $\alpha, \beta, \gamma$ & 11.14 & $<0.001 * *$ \\
\hline ANOVA test & 118.6 & & & & & & \\
\hline $\mathrm{P}$ value & $<0.00$ & & & & & & \\
\hline
\end{tabular}

$\alpha$ : sig versus control group $\quad \beta$ : sig versus Gp Ia $\quad \gamma$ : sig versus Gp Ib

$\delta$ : sig versus Gp IIa $\quad * *$ : highly significant 


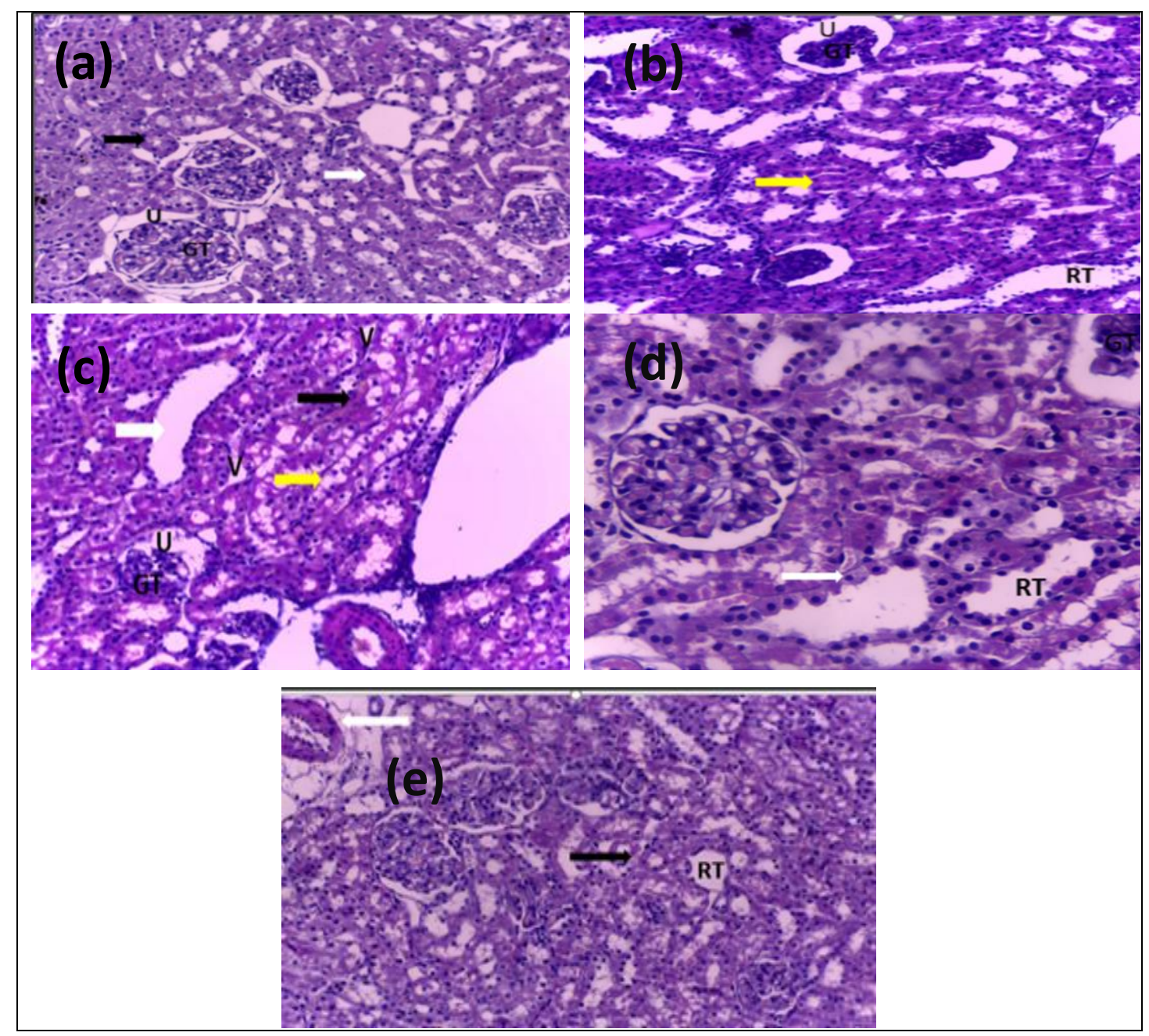

Image 1. Histopathological sections from kidney of rats: (a) normal histological structure in the control group.M:X200 (b) corpuscles of kidney showing atrophic changes with contraction in glomerular tuft (GT) and wide in urinary space (U), degeneration of renal tubular epithelium with luminal dilatation (RT) and hydropic degeneration of epithelium (yellow arrow) in test group Ia .M:X200,(c) corpuscles of kidney showing atrophic changes with contraction in glomerular tuft (GT) and wide in urinary space (U), luminal dilatation (RT) and hydropic degeneration of epithelium (yellow arrow) extravasation of RBCS (black arrows) \& interstitial vacuolations (V) in the test groups Ib,M:200, (d) corpuscles of kidney showing atrophic changes with contraction in glomerular tuft (GT) and wide in urinary space (U) Hydropic degeneration of renal tubular epithelium with luminal dilatation (RT) with nuclear pyknosis (white arrow) in the test group IIa . M : 400, (e) congestion of blood vessels (white arrow), and hydropic degeneration of renal tubular epithelium with luminal dilatation (RT) \& extravasation of RBCS (black arrow) in the test group IIb. Magnification: X200. 


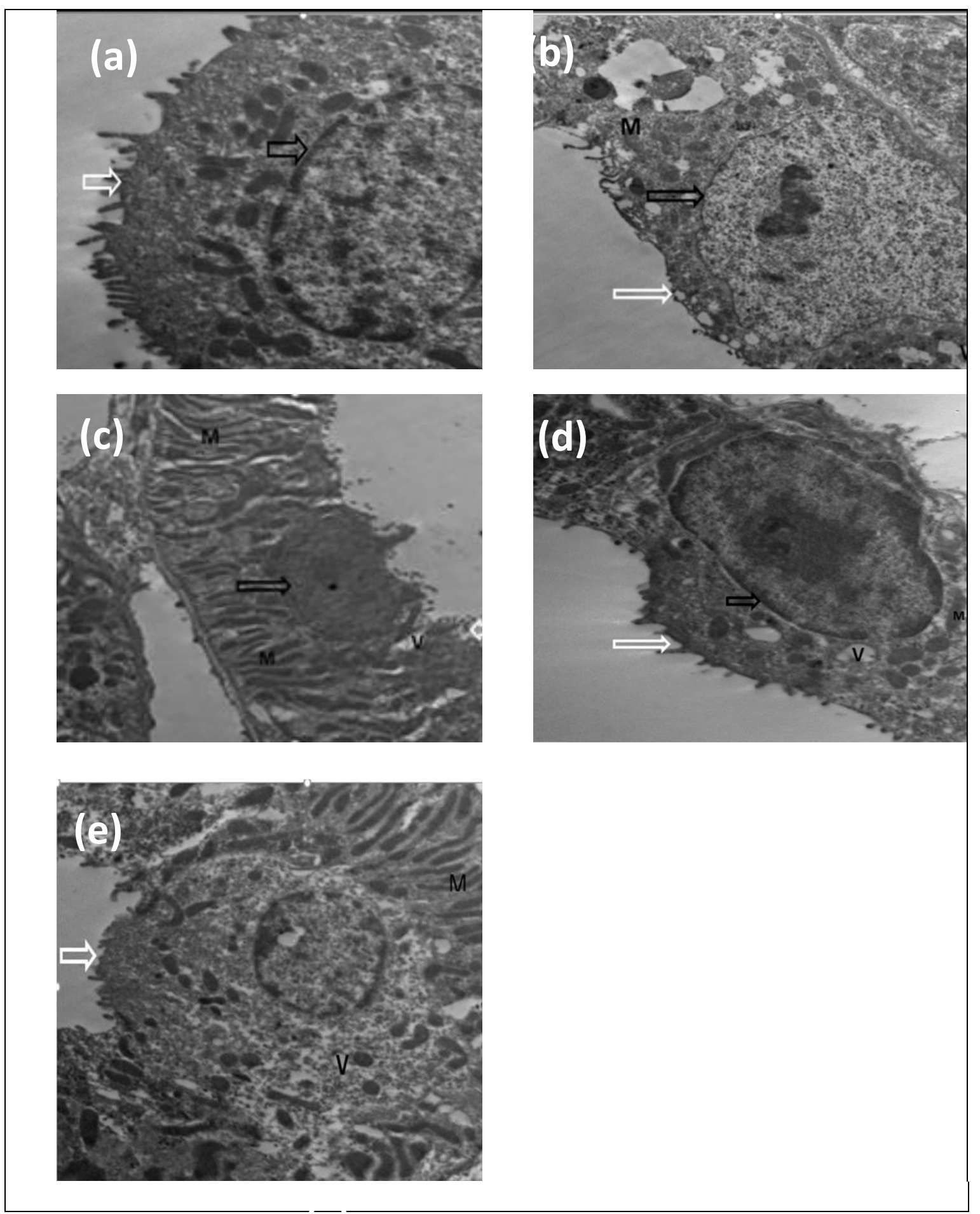

Image 2. Electron photomicrographs of distal convoluted tubules of rat kidney: (a) normal structure in the control group, (b) irregular nucleus with rarefaction (black arrow), vacuolation in mitochondria (M), vacuolation in cytoplasm (V) \& lost brush border (white arrow) in the test groups la .M:1500, (c) irregular nucleus (black arrows) elongated mitochondria (M), vacuolations in cytoplasm (V)\& destructed brush border (white arrows).M:1500, ( $d$ \& e) vacuolations in cytoplasm (V)\& preserved brush border (white arrows)elongated mitochondria $(\mathrm{M})$ in the test groups Ila and IIb respectively. Magnification: X1500. 

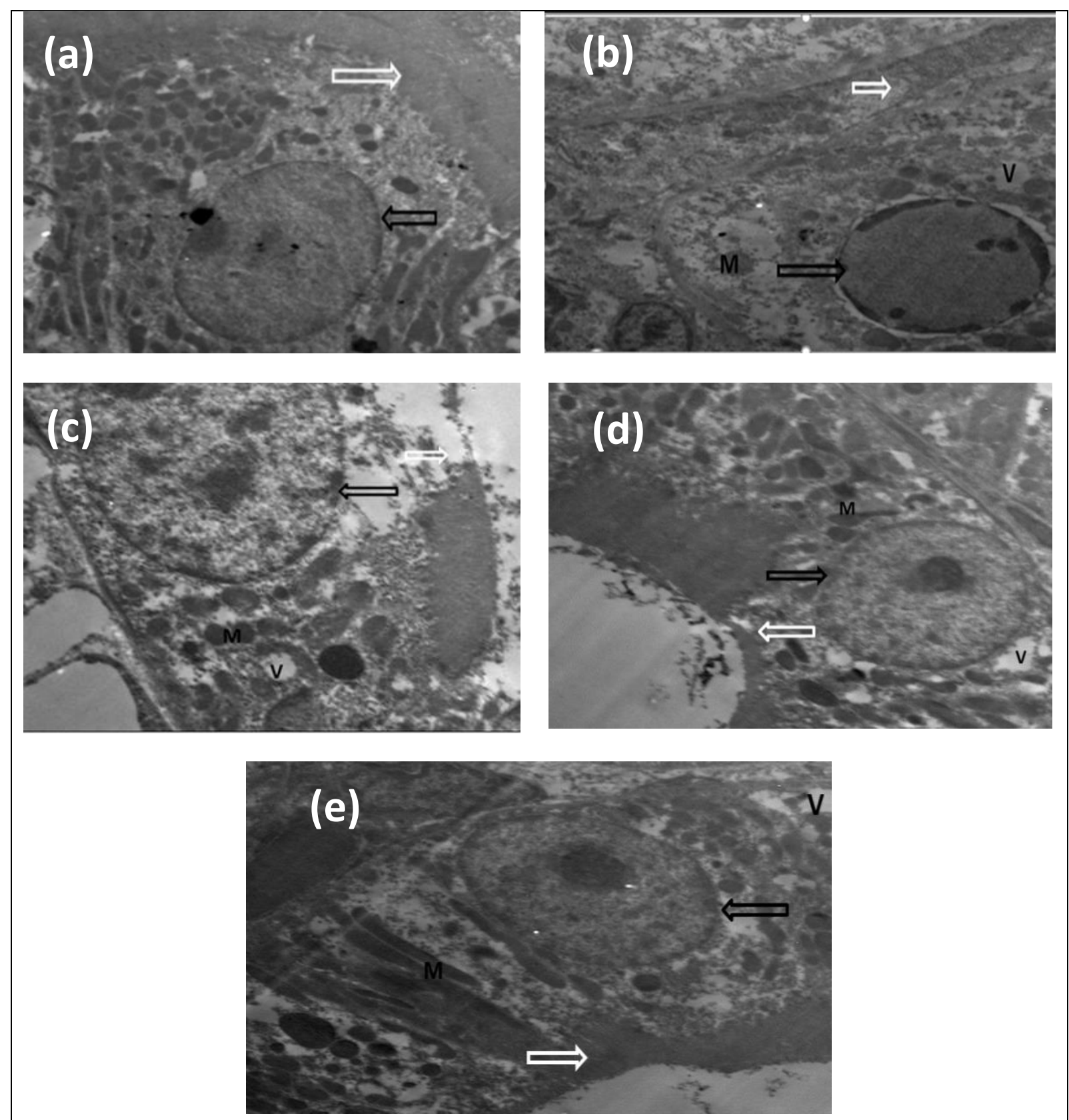

Image 3. Electron photomicrographs of proximal convoluted tubules of rat kidney: (a) normal structure in the control group, (b) apoptotic nucleus with chromatin at periphery and perinuclear spacing (black arrows) deformation and vacuolation of mitochondria (M) vacuolation in cytoplasm (V) lost brush border (white arrow) in test group Ia .M:2000, (c) rarefaction in nucleus (black arrow), deformation and vacuolation of mitochondria (M), vacuolation in cytoplasm (V) \&lost brush border (white arrow) in test group Ib.M:2500, (d, e) regular nucleus (black arrow) vacuolation in (V) mitochondria deformed (M) irregular brush border (white arrow) in the test groups IIa and IIb respectively. Magnification: X1500. 

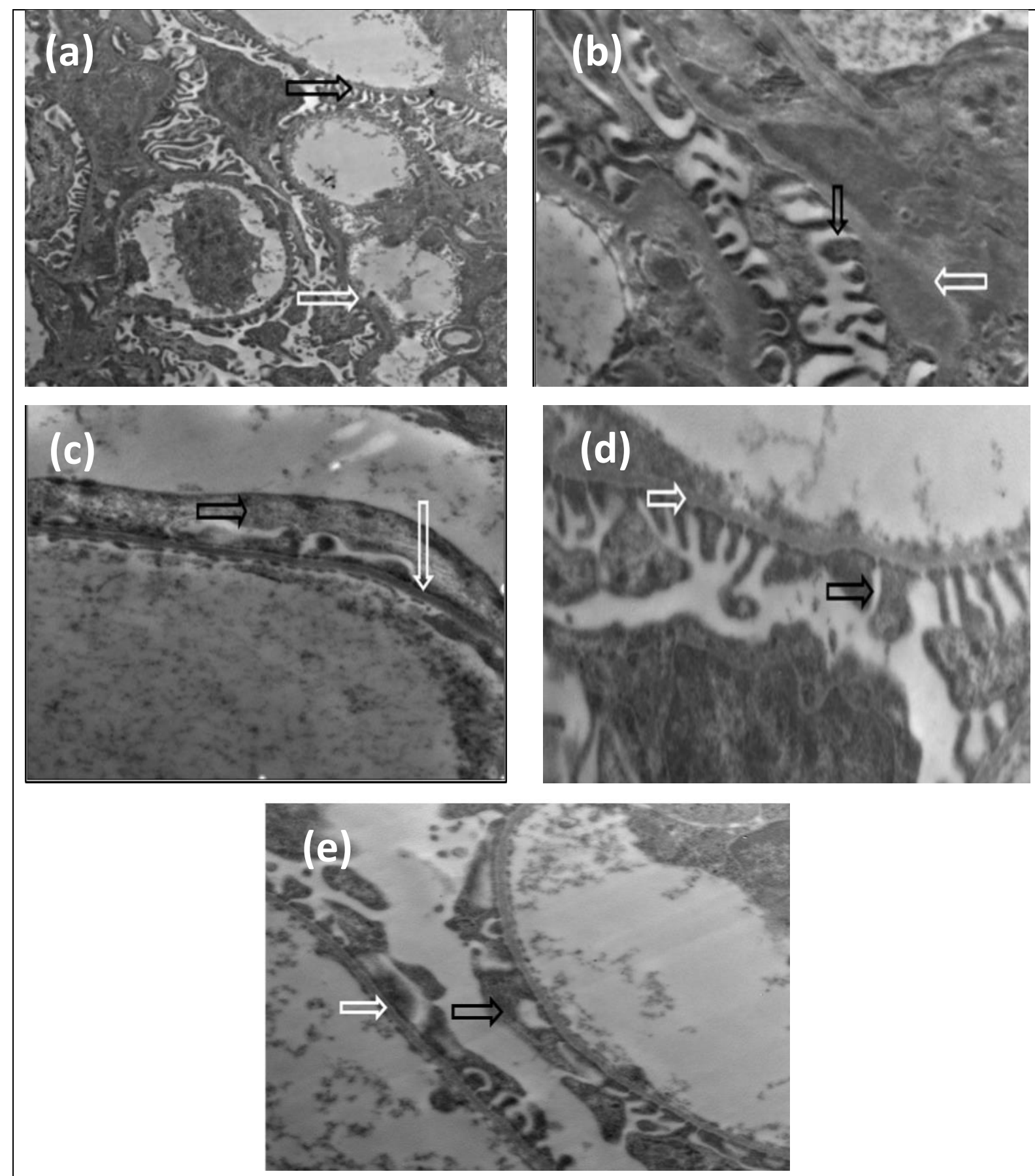

Image 4. Electron photomicrographs of rat kidney: (a) normal structure in the control group, (b) largely enlarged foot processes of podocytes (black arrow) \& high degree of thickening of basement membrane (white arrow) in test group Ia, M:4000, (c) enlarged foot processes of podocytes (black arrow) \& thickening of basement membrane (white arrow) in test group IIb .M :4000, (d \& e) enlarged foot processes of podocytes (black arrow) \& thickening of basement membrane (white arrow) in the test groups IIa and IIb respectively,. Magnification: X400. 


\section{DISCUSSION}

Frequent (PPD) exposure has deleterious effect on both kidney structure and function, emphasized by increased levels of urea nitrogen which indicate decreased of the kidney ability to excrete the toxic metabolites (Bharali et al., 2012). Furthermore, the oxidative stress resulted from exposure to (PPD) can induce cystic changes in the ovary (Sharma et al., 2015).

Regarding renal functions, the present study revealed a high increase in urea \& creatinine levels in all test groups as compared to control groups.

These results are matched with the results of previous study by (Hummdi, 2012) who reported a high increase in both blood urea and serum creatinine levels due to PPD exposure in rats.

The possible underlying mechanism of renal damage could be due to PPD induced rhabdomyolysis that causes release of myoglobin, which obstructs renal tubules, react with renal tubular proteins or lead to necrosis in renal tubules (Shalaby et al., 2010).

In the current study, levels of urea \& creatinine were more significantly elevated in test groups Ia \& Ib (PPD dissolved in water) than in test groups IIa \& IIb (PPD dissolved in $\mathrm{H}_{2} \mathrm{O}_{2}$ ).

These findings could be attributed to poor absorption of Hydrogen peroxide through intact skin; as around $0.6 \mathrm{mg} / \mathrm{kg}$ per day can be absorbed (HERA, 2005 and Kumar\& Mainigi, 2017).

Moreover, there was a significant difference between test group Ia (shaved) and Ib (hairy) and no significant difference between test group IIa (shaved) and IIb (hairy) in the current work.

These findings can be explained by the fact that hair can absorb around $30 \%$ of its own weight of water (Saitta et al., 2013) and the cuticle which is the outer most layer of hair, is covered by a layer of lipids that makes the hair repels water (Bontozoglou et al., 2019). The hair resistance is due to the presence of bonds, which maintain the reticular integrity and avoids penetration of molecules in a volume which is more than the existing one between protein chains (Velasco et al., 2009).

In the present study the histopathological changes supported the evidence of alteration in renal functions, as sections of rat kidney in all test groups, as compared to control groups, revealed atrophy of corpuscles of kidney with retraction of glomerular tuft and wide urinary space, degenerative changes of renal tubules and hydropic degeneration of epithelium. However, the degenerative changes were more severe in test group Ia and Ib with additionally further changes including; tubular cast, congestion of blood vessels and mononuclear cell infiltration.

Sampath and Yesudas (2009), reported acute tubular degeneration in humans exposed to para phynelendiamine toxicity and revealed degeneration of renal tubular epithelium with luminal dilatation and mononuclear cell infiltration similar to our result.

In the present study, the electron microscopic examination of the kidney revealed enlargement of foot processes of podocytes, thickened basement membrane of Bowman's capsule and destruction to distal convoluted tubules (irregular nuclei, deformation and vacuolation in mitochondria, vacuolation in cytoplasm, destructed and lost brush border), inter tubular congestion of blood vessels with infiltration of macrophage, monocytes and plasma cell. Also, proximal convoluted tubules showed irregular nucleus \& rarefaction due to destructed chromatin in nucleus, deformation and vacuolation in mitochondria, vacuolation in cytoplasm \& destructed brush border. These degenerative changes were detected in all test groups as compared to controls. All degenerative changes were more sever in test group Ia \& Ib (PPD dissolved in water).

These injuries resulting from dehydration, hypoxia, haemolysis in vessels, methaemoglobinaemia and direct side effects of chemical or its byproducts on tubules of kidneys (Kumar, 2012).

Other possible mechanisms that may be involved in PPD induced renal injuries are either oxidative stress or reactive intermediates. Oxidative stress is manifested by increased 
release of reactive oxygen species (ROS), which lead to lipid peroxidation, inactivate cellular enzymes, polysaccharides depolarization and break in deoxyribonucleic and chromosome Reactive intermediates react covalently to critical cellular macromolecules and prevent normal biologic function (Hummdi, 2012).

\section{CONCLUSION}

This study revealed that the dermal exposure of rats to PPD results in damages in the kidney. This is proved by the biochemical changes that are consistent with the tissue damage. Thus, in case of renal injury of unknown origin, we must investigate the history of hair dye use.

\section{RECOMMENDATIONS}

-PPD handlers such as hair dresser, textile manufacturing workers, and chronic tattoo users should be subjected to serial biochemical follow up parameters renal.

-The mentioned risk group populations should have protective measures decreasing chronic hazardous of PPD as protective gloves, overalls, and masks.

-Hair dye products that are used must have their ingredients wrote on the label. Also, the public should be aware of the other chemical names of para-phenylendiamine such as phenylenediamine, PARA, 1, 4phenylenediamine, 1, 4-diaminobenzene 6PPD, p-benzenediamine, p-diaminobenzene, black for fur D,Paminoaniline.

-Further investigation is required to explore the mechanism of action of paraphenylene diamine.

-Continuous usage of hair dye containing PPD must be avoided.

\section{ACKNOWLEDGEMENT}

Our deep appreciation to the staff members of Forensic Medicine and Clinical Toxicology; Faculty of medicine, Benha University, and in Faculty of Veterinary medicine for their cooperation.

\section{REFERENCE}

Abass, A. Elk; mobasher, N.; Ali, F.; Salah, R. and Mohamed, N. (2017): "Haematological and Biochemical findings of Hair Dye Poisoning." IOSR Journal of Pharmacy; 7 (12):120-127.

Al Saif,F. (2016): Henna beyond skin arts: Literatures review. Journal of Pakistan Association of Dermatologists; 26 (1):58-65.

AlSeigini; et al. (2014): Assessment of DNA Damage on Adult Albino Rats Induced by Dermal Exposure to P-Phenylenediamine (PPD). Ain Shams J Forensic Med Clin Toxicol; (23):173-181.

Bharali, M.K.; Basumatary, R.; Rahman, T.; et al. (2012): Repeated Topical Application of para-Phenylenediamine Induces Renal Histopathological Changes in Rats. Toxicology Intenational Journal; 19(2):1327.

Bontozoglou, C.; Zhang,X.; Patel,A.; Lane,M.E. and Xiao,A. (2019): In Vivo Human Hair Hydration Measurements by Using Opto-Thermal Radiometry, International Journal of Thermophysics; 40:22.

ElHelaly and Shaker (2014): Repeated Dermal Paraphenylenediamine Exposure Induces Systemic Biochemical and Histological Changes in Adult Male Albino Rats. Ain Shams J Forensic Med Clin Toxicol; (23):71-89.

Elkhomainy, M. A. N. (2017): The Toxicological Effects of-

Paraphenylenediamine on Albino Rats A thesis submitted for the partial fulfillment of M.Sc. degree in forensic science NATIONAL UNIVERSITY INSTITUTE 
OF FORENSIC SCIENCES International Journal of Cancer; 91(4): 575-579.

Gouma, E. Y.; Simos, Y.; Verginadis, I.; et al. (2011): A simple procedure for estimation of total body surface area and determination of a new value of Meeh's constant in rats. Lab Anim; 46-40.

Hassan; et al. (2017): Para Phenylene Diamine Poisoning: Hepatic and Renal Damage. J Women's Health Care; 6:2.

HERA, (2005): Human \& Environmental Risk Assessment on ingredients of household cleaning products, Hydrogen Peroxide; 1.

Hummdi, L.A. (2012): Histopathological Alterations in Renal Tubules of Female Rats Topically Treated with-

Paraphenylen Diamine World Applied Sciences Journal; 16 (3): 376-388.

Kumar, S. (2012): suicide by para. phenylenediamine Poisoning. J. Indian Acad Forensic Med; 32(2): 163-164.

Kumar, D. and Mainigi, (2017): CENTER FOR DRUG EVALUATION AND RESEARCH APPLICATION-

NUMBER: 209305Orig1s000 Reference ID: 4165813.

Malik, S.; Noor, U.; Baqar, A.; Qamar, K.H.; (2018): Mdullary Congestion in ovary of topically applied PPD effected rats. Pak Armed Forces Med J; 69 (1): 187-91.

Lee, S.H and Lee, S.I. (2006): effect of mixture of PPD with hydrogen peroxide on rat skin. Journal of Korean society and food science and nutrition; 35 (8):1010-101.
Malik, S., Qamar, K. and Rehman, S. (2016): Paraphenylene diamine induced histomorphological changes in rat ovary. Pak J Pathol; 27(3): 124-129.

Saitta, p.; Messina, J. L.; Brancaccio, R.; Benedict, C. W.; Steven, K. G. and Holland, $J$. (2013): A Review of the Epidemiological Evidence Relating Personal Hair Dye Use to the Risk of Malignanc. J Clin Aesthet Dermatol; 6(1): 39-4.

Sampath, K.K. and Yesudas, S. (2009): Hair dye poisoning and the developing world. J Emerg Trauma Shock. 2(2): 129-131.

Shalaby; et al. (2010): Clinical profile of acute paraphenylenediamine intoxication in Egypt. Toxicology and Industrial Health; 26(2): 8187.

Sharma, D.; Sangha, G.K. and Khera, K.S. (2015): Triazophos-induced oxidative stress and histomorphological changes in ovary of female Wistar rats. Pesticide biochemistry and physiology; 117: 9-18.

Velasco, M.V.R.; Dias, C.D. E.; Freitas, A.Z.; Júnior,N.D.V.;et al. (2009): Hair fiber characteristics and methods to evaluate hair physical and mechanical properties. Brazilian Journal of Pharmaceutical Sciences; 45: 1.

Zanoni, T.B.; Hudari, F.; Munnia, A.; Peluso, M.; Godschalk, R.W.; Zanoni,M.V.; et al. (2015): The oxidation of $p$ phenylenediamine, an ingredient used for permanent hair dyeing purposes, leads to the formation of hydroxyl radicals: Oxidative stress and DNA damage in human immortalized keratinocytes. Toxicology letters; 239(3):194-204. 


\section{الـمـلـخص الـعـربـى}

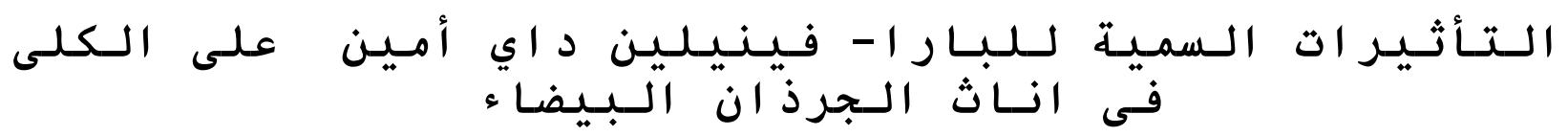

طا أميمة رفعت محمد ، أ.د/ نيرمين عدلى محمود, أ.م.د/ اسلام سامى متولى, أ.م.د/ أسماء يس عبدالخالق حسين قسم الطب الثرعى و السموم الاكلينيكية, كلية الطب البشري - جامعة بنها - مصر

البارا فينيلين داى أمين عبارة عن مادة كيميائية تستخدم بشكل أساسي في تركيب حبر الطباعة ، ومحاليل التصوير الفوتوغرافي ، والنسخ ، والوشم المؤقت ، ومستحضرات التجميل ذات الألوان الداكنة ، وما يقرب من 1500 من منتجات تلوين الشعر التى تحتوي على البارا فينيلين داى أمين •إن التعرض المتكرر للبارا فينيلين داى أمين له تأثير ضار على بنية الكلى ووظيفتها في إناث الجرذان، يدل على ذلك ارتفاع مستويات المصل من نيتروجين اليوريا والتي تشير إلى انخفاض قدرة الكلى على التخلص من نواتج الأيض السامة ـهدفت الدراسة الحالية إلى تقييم التأثيرات السمية لمادة بارا فينيلين ديامين على الكلى فى إناث الجرذان البيضاء.كانت الفترة التجريبية الإجمالية للدراسة 60 يومً، من 2020/2/1 حتى 2020/4/1. تم تقسيم 72 أنثى من الجرذان البيضاء البالغة بشكل عشوائي إلى أربع مجموعات على النحو التالي:مجموعة ضابطة سلبية, مجموعة ضابطة ايجابية, مجموعة الاختبار الاولى: محلول البارا فينيلين داى أمين في الماء المقطر (10 مجم / كجم / اليوم) على الجلد المحلوق ، ومحلول البارا فينيلين داى أمين في الماء المقطر (10 مجم / كجم / اليوم) على الجلد المشعر ؛ مجموعة الاختبار الثانية: محلول البارا فينيلين داى أمين المذاب في ماء اكسجين( 10 مجم / كجم / يوم) على الجلد المحلوق, ومحلول البارا فينيلين داى أمين مذابة في ماء اكسجين( 10مجم / كجم / اليوم) على الجلد المشعر . تم قياس مستويات الكرياتينين واليوريا ، و تم فحص أنسجة الكلى بواسطة المجهر الضوئي والمجهر الإكتروني الناقل. النتائج: أظهرت الدراسة الحالية زيادة في مستوبات اليوريا والكرياتينين في الدم ،كما اظهر فحص الأنسجة للكلية في كل مجموعات الاختبار حدوث تغيرات هستوباثولوجية بالمقارنة مع المجموعات الضابطة. توصلت الدراسة الى اثبات التأثيرات السمية لمادة البارافنيلين داى أمين على الكلي فى اناث الجرذان البيضاء. 